\title{
Ubiquitin Protein Measurement
}

National Cancer Institute

\section{Source}

National Cancer Institute. Ubiquitin Protein Measurement. NCI Thesaurus. Code C147443.

The determination of the amount of ubiquitin present in a sample. 